\title{
UŻYTECZNOŚĆ BADAWCZA STRUKTUR SIECIOWYCH W NAUCE O STOSUNKACH MIĘDZYNARODOWYCH
}

\author{
USABILITY OF NETWORK STRUCTURES IN THE RESEARCH OF \\ INTERNATIONAL RELATIONS
}

\author{
Wojciech Stachyra (ㅇ
}

\begin{abstract}
- ABSTRAKT
Artykuł zawiera argumentację na rzecz wykorzystania w nauce o stosunkach międzynarodowych metod badawczych opartych na analizie struktur sieciowych. Wychodząc od ogólnej definicji sieci jako struktury złożonej z połączonych relacjami elementów, ukazuje jej odpowiedniość do opisu procesów i zjawisk o charakterze transgranicznym. Idąc dalej, rozważa komplementarność sieci w stosunku do kategorii badawczej systemu międzynarodowego i metody analizy systemowej, która przedstawia się jako szczególny przypadek szerszej klasy sieciowych metod badawczych. Analiza dotychczasowych, udanych prób adaptacji w naukach społecznych matematycznej teorii grafów, pozwala na zaproponowanie ogólnego modelu analizy sieciowej, który może okazać się użyteczny przy badaniu stosunków międzynarodowych.
\end{abstract}

Słowa kluczowe: stosunki międzynarodowe; metodologia; system międzynarodowy; sieci; teoria grafów
The presented article contains argumentation supporting the use of network structure analysis as a method of research in International Relations. By applying the general definition of the network as a structure built with a set of interconnected elements, it can be shown that such a method is suitable for description of transborder processes and phenomena. Under this reasoning, the article explores the complementarity of the network approach in relation to the international system research category and the method of systemic analysis. The latter appears to be a specific case of the broader class of network methods. The comparison of previous, successful attempts at application of the mathematical graph theory in social research allows for making a proposal of a general model of network analysis in International Relations.

Keywords: international relations; methodology; international system; networks; graph theory

\footnotetext{
* Uniwersytet Marii Curie-Skłodowskiej w Lublinie, Szkoła Doktorska Nauk Społecznych.
} 


\section{WSTĘP}

Współczesne stosunki międzynarodowe charakteryzują dwie istotne tendencje. Pierwszą z nich jest poszerzanie się ich zakresu podmiotowego - oprócz państw narodowych i tworzonych przez nie organizacji, coraz istotniejszą rolę odgrywają w nich podmioty niepaństwowe. Drugą tendencją jest poszerzanie się ich zakresu przedmiotowego. Obok płaszczyzn tradycyjnych: politycznej, militarnej i gospodarczej, intensywnej internacjonalizacji podlegają także sfery: społeczna, kulturalna, ekologiczna, informacyjna i inne. Oba opisane wyżej procesy można zbiorczo opisać jako swego rodzaju narastanie przestrzeni międzynarodowej. Nie ma ono bynajmniej charakteru abstrakcyjnego, lecz posiada konkretny wymiar strukturalny w postaci gęstniejących sieci powiązań, współzależności, interakcji między uczestnikami stosunków międzynarodowych. Można powiedzieć, że stosunki te podlegają procesowi postępującego „usieciowienia”.

Zmiana rzeczywistości zawsze powinna pociągać za sobą zmiany $\mathrm{w}$,intelektualnym oprzyrządowaniu” badających ją dyscyplin nauki (Pietraś, 2015). Ponieważ celem tych zmian jest poznanie prawdy o świecie, istnieje konieczność nieustannego pytania o adekwatność wspomnianego oprzyrządowania do rzeczywistości. Zważywszy na wagę i dynamikę opisanych w poprzednim akapicie przemian środowiska międzynarodowego, pytanie to jest w kontekście nauki o stosunkach międzynarodowych w pełni uzasadnione. Celem niniejszego artykułu nie jest udzielenie na nie kompleksowej odpowiedzi. Ze względu na obiektywne cechy rzeczywistości społecznej oraz niedoskonałość ludzkiego poznania zawsze będzie istniała pomiędzy nimi luka. Zamiast tego, celem jest zwrócenie uwagi na możliwość zmniejszenia wspomnianej luki przez wykorzystanie w badaniach nowego, obiecującego narzędzia badawczego - sieci. Wydają się one nie tylko umożliwiać opis wielowymiarowych procesów mających miejsce w komplikującej się rzeczywistości, ale także pozwalają na wykrycie kluczowych prawidłowości ich rozwoju.

Argumentacja za użytecznością sieci zostanie przeprowadzona $\mathrm{z}$ trzech pozycji. Po pierwsze: ogólnych własności sieci i ich odpowiedniości do opisywania stosunków międzynarodowych. Po drugie, poprzez wskazanie na sieciową naturę systemu międzynarodowego oraz komplementarność sieci w stosunku do metody badawczej analizy systemowej. Może być ona w twórczy sposób rozwinięta i uogólniona jako jedna $\mathrm{z}$ metod sieciowych. W trzecim kroku, na podstawie doświadczeń badań z zakresu socjologii, ekonomii i politologii, które wykorzystywały struktury sieciowe, zaproponowany zostanie ogólny schemat 
badań sieciowych. W przyszłości może się on okazać przydatny dla badań stosunków międzynarodowych.

\section{SIECI W STOSUNKACH MIĘDZYNARODOWYCH}

We współczesnym świecie, który $\mathrm{w}$ istotny sposób definiowany jest przez gwałtowny rozwój naukowo-technologiczny, wyraz „sieć” funkcjonuje przede wszystkim jako synonim Internetu. Należy jednak zwrócić uwagę, że równie dobrze nadaje się on do opisu szeregu innych fragmentów rzeczywistości. W sensie najbardziej ogólnym sieć jest dowolną strukturą złożoną z elementów połączonych relacjami i jest synonimem grafu. (Oh, Monge, 2016) Elementy sieci nazywane „węzłami” lub „wierzchołkami” mogą reprezentować zarówno komputery, jak i miejscowości na mapie, pojedynczy ludzie, grupy społeczne, państwa oraz każdy inny przedmiot zainteresowań (Dumała, 2012). Linie łączące wierzchołki i nazywane „krawędziami”, odpowiadają istniejącym pomiędzy wierzchołkami relacjom - wzajemnemu skomunikowaniu, zależnościom, interakcjom i przepływom (Wilson, 2012). Tak zdefiniowana sieć charakteryzuje się bardzo dużą „ppojemnością znaczeniową" i jest właściwie meta- strukturą: czystą, abstrakcyjną formą, za pomocą której można odwzorować i przeanalizować każdą inną strukturę (Rapaport, 1976). Szczególnego znaczenia sieć nabiera w kontekście rzeczywistości społecznej, której podstawowym budulcem są relacje pomiędzy jednostkami, grupami społecznymi, organizacjami czy państwami. Wszystkie te rodzaje podmiotów odgrywają istotną rolę we współczesnych stosunkach międzynarodowych.

Kategoria 'sieci' w nauce o stosunkach międzynarodowych została po raz pierwszy zastosowana najprawdopodobniej przez Johna W. Burtona (1972). Opisując międzynarodowe powiązania społeczne, użył on metafory „pajęczyny”, a więc właśnie sieci. Inną, klasyczną już pozycją, w której pojawiło się odwołanie do struktur sieciowych, jest książka Manuela Castells'a „Społeczeństwo Sieci” (1996), traktująca o wpływie rewolucji technologicznej na życie społeczeństw. Przez obu wspomnianych autorów termin „sieć” traktowany był nie tyle jako kategoria badawcza, co wygodny i obrazowy sposób scharakteryzowania przemian rzeczywistości. Wydaje się, że taki sposób posługiwania się tym pojęciem utrwalił się w literaturze przedmiotu. Jako „struktury sieciowe” określa się bowiem najczęściej niepaństwowych uczestników stosunków międzynarodowych, mając na uwadze ich swoiste „rozmycie w przestrzeni” wynikające z równoczesnej 
obecności w wielu miejscach globu, zdecentralizowaną strukturę i nieformalny charakter, przynajmniej części tworzących je powiązań (Pietraś, 2007). Pojęciem sieci posługują się także badacze więzi i procesów transnarodowych, którzy wskazują, że rozciągają się one niejako „w poprzek” granic państw narodowych, przy ograniczonym udziale lub zgoła z pominięciem organów władzy centralnej (Dumała, 2012).

Z powyższych rozważań wynika, że sposób rozumienia sieci jest oparty na założeniu, że stanowią one horyzontalną strukturę współpracy. Jak wskazuje Hanna Dumała (2012, s. 210): „Organizacja sieciowa traktowana jest przez badaczy, jak i aktorów uczestniczących w sieci, jako alternatywa dla dwóch dominujących dotychczas mechanizmów interakcji: rynku i hierarchii. Rynek oznacza przepływ zasobów oparty na konkurencji i rywalizacji. Hierarchia to charakterystyczne dla struktur państwowych podporzadkowanie i nadzór. Sieć jest więc trzecią- pośrednią między rynkiem a hierarchią formą organizacji zarządzania”. Nie negując prawdziwości tej tezy, należy stwierdzić, że nie wynika ona $\mathrm{z}$ ogólnej definicji sieci, ale jest wynikiem doświadczeń płynących z badań ich specyficznego rodzaju. W stosunku do wszystkich sieci, jakie można napotkać w stosunkach międzynarodowych, powyższy punkt widzenia jest jednak zbyt daleko idącym uproszczeniem. Rozważając pojęcie sieci w jej najogólniejszym znaczeniu, bez przyjmowania jakichkolwiek wstępnych założeń na temat jej kształtu lub sposobu funkcjonowania, łatwo jest bowiem zauważyć, że zarówno rynek, jak i hierarchia, zbudowane są z połączeń rozpiętych pomiędzy podmiotami, i z tego powodu również one mogą być rozważane jako sieci. Różnica pomiędzy nimi polega jedynie na sposobie interpretacji wierzchołków oraz krawędzi sieci. Dla pierwszego z nich (rynek) wierzchołkami będą przedsiębiorstwa, a krawędziami przepływy czynników produkcji, w drugim przypadku (hierarchia) wierzchołki to instytucje, a krawędzie odzwierciedlają stosunki podległości i władzy. Kształt obydwu struktur znacząco się różni, co w niczym nie zmienia faktu, że obie struktury są sieciami. Patrząc z tego punktu widzenia, znacznie bardziej uzasadnione jest zatem mówienie o różnych rodzajach sieci społecznych niż wiązanie całego pojęcia sieci z jednym tylko, specyficznym sposobem zorganizowania (Rappaport, 1976).

Horyzontalność i nastawienie na współpracę jak najbardziej odnoszą się do sieci transnarodowych. Nie należy ich jednak ekstrapolować na wszystkie sieci społeczne i transgraniczne. Krawędzie sieci równie dobrze mogą odpowiadać relacjom konkurencji, współpracy, podległości, władzy czy po prostu kontaktu i wzajemnej świadomości istnienia partnera. Dla opisu wszystkich tych sytuacji 
struktura sieciowa sprawdza się równie dobrze, oddziałując konstruktywnie również na realizację dwóch pozostałych funkcji nauki: wyjaśniania i modelowania rzeczywistości (Kowalska-Musiał, 2013).

Środowisko międzynarodowe ma charakter anarchiczny (Pietraś, 2007), co oznacza, że brak jest w nim władzy nadrzędnej, której jurysdykcji poddani byliby wszyscy uczestnicy stosunków międzynarodowych. Innym sposobem opisu tego stanu jest kategoria 'poliarchiczności', rozumiana jako istnienie wielu, autonomicznych ośrodków władzy. Wychodząc od tych elementarnych faktów, można stwierdzić, że środowiskiem międzynarodowym rządzi logika horyzontalna. Idąc w rozważaniach o krok dalej, dochodzi się jednak do wniosków zgoła przeciwnych. Poliarchiczność wymusza na uczestnikach stosunków międzynarodowych postępowanie w myśl zasady samopomocy, polegającej na gromadzeniu i inwestycyjnym wydatkowaniu siły w procesach wywierania wpływu na otoczenie (Czaputowicz, 2008). Biorąc pod uwagę względne nadwyżki i deficyty siły, wśród aktorów międzynarodowych można wyróżnić faktyczną hierarchię. Mamy tu bowiem do czynienia ze swoistym paradoksem logiki środowiska międzynarodowego. Równorzędność de iure prowadzi do hierarchiczności de facto i vice versa. Paradoks ten znajduje rozwiązanie na gruncie sieci.

Historycznie rzecz ujmując, pierwsze organizmy państwowe powstawały w pewnej izolacji od siebie, wchodząc we wzajemne interakcje w miarę ekspansji i rozwoju. W ten sposób z upływem czasu kształtowała się transgraniczna sieć oddziaływań i powiązań międzypaństwowych, w ramach której dokonywały się przepływy siły. Te państwa, które zyskiwały jej względną nadwyżkę, mocniej modelowały środowisko międzynarodowe, stając się mocarstwami (Woosang, Gates; 2015). Wraz z upływem czasu stosunki międzynarodowe przeszły daleko idące zmiany. Oprócz tradycyjnych płaszczyzn: politycznej, militarnej i ekonomicznej, pojawiły się inne, takie jak społeczna, kulturalna, ekologiczna, aksjologiczna czy sportowa. Wzrosła także liczba i różnorodność uczestników stosunków międzynarodowych. Wszystkie te zmiany nie doprowadziły jednak do zmiany samej zasady zorganizowania stosunków międzynarodowych, pozostających wielowymiarową siecią powiązań, współzależności, oddziaływań, przepływów i relacji (por. Waltz, 2010), w stosunku do której hierarchiczność i horyzontalność stosunków międzynarodowych okazują się być emergentne i wtórne.

Zaszłości historyczne oraz tradycje i schematy myślowe obecne w nauce o stosunkach międzynarodowych sprawiały, że w różnych paradygmatach badawczych na pierwszy plan wybijała się jedna bądź druga, podczas gdy być może jest 
tak, że to heterarchiczna sieć łącząca w sobie elementy obydwu porządków jest bardziej odpowiednim terminem opisującym rzeczywistość międzynarodową (Miura, 2003; Baumann, Dingwerth, 2014)?

\section{SYSTEM MIĘDZYNARODOWY JAKO STRUKTURA SIECIOWA}

Sposób widzenia rzeczywistości jako sieci dobrze oddaje wyraz „system”. Statusu kategorii badawczej nabrał on w początkach XX wieku, kiedy to Ludwig von Bertalanffy zdefiniował go jako: „zbiór komponentów, pozostających we wzajemnych relacjach umożliwiających identyfikację granic pomiędzy poszczególnymi komponentami lub procesami” (Pawłuszko, 2014). Celem von Bertalanffy'ego było zastosowanie konstrukcji systemu jako teoretycznej ramy dla całej nauki, której poszczególne dziedziny już wówczas zaczynały się od siebie oddalać. Z drugiej strony zaproponowany pierwotnie jako narzędzie unifikujące system okazał się bardzo przydatnym narzędziem analitycznym i szybko został zaadaptowany na grunt nauk szczegółowych.

W nauce o stosunkach międzynarodowych kategoria badawcza systemu odgrywa kluczową rolę. Barry Buzan i Richard Little (2011) podnieśli ją nawet do rangi jej „pojęciowego wyróżnika”. Mimo tego w literaturze nie przyjęła się jedna, powszechnie akceptowana definicja systemu (por. Kondrakiewicz 2015). W praktyce dyskursu naukowego badacze posługują się tym pojęciem powszechnie, rozumiejąc go w podobny sposób, jednak w kontekście konkretnych badań, nierzadko definiując w sprzeczny sposób. Jak się wydaje, najbliżsi sformułowania ogólnej definicji systemu międzynarodowego byli w literaturze autorzy, którzy wychodząc od obserwowanej rzeczywistości, nie tyle interpretowali ją, co starali się uchwycić jej najważniejsze cechy. Tak na przykład A-M. Slaughter (2004, s. 145) stwierdziła, że specyfiką współczesnego systemu międzynarodowego jest „łączenie się państw i aktorów pozapaństwowych w skomplikowany model relacji zarówno wertykalnych, jak i horyzontalnych, tworząc rozległe i wielowymiarowe sieci". Do podobnych wniosków, choć na gruncie stricte teoretycznym, doszedł D. Kondrakiewicz (2016, s. 82). Po dokonaniu wyczerpującego przeglądu istniejących w literaturze definicji systemu międzynarodowego stwierdził on, że w ogólności pojęcie to odnosi się do „skomplikowanej sieci powiązań i relacji między uczestnikami stosunków międzynarodowych, charakteryzującej się rosnącym poziomem złożoności, wzajemnych zależności i hierarchicznego zróżnicowania”. 
Każda $\mathrm{z}$ wymienionych definicji wyprowadzona została $\mathrm{z}$ odmiennych przesłanek. Pierwsza powstała w wyniku rzeczowego odnotowania obserwowanych tendencji rozwoju stosunków międzynarodowych. Druga została oparta na analizie porównawczej obecnych w literaturze ujęć problemu i na bazie ich elementów wspólnych zaproponowano definicję unifikującą. Tym znamienniejsze jest, że obie są w gruncie rzeczy równoważne i - co z perspektywy tych rozważań kluczowe - opisują swój desygnat jako strukturę sieciową. Tym samym teza o odpowiedniości perspektywy sieciowej do badania stosunków międzynarodowych zyskuje wsparcie również ze strony dotychczasowego stanu teorii.

W 1953 roku kanadyjski politolog David Easton opublikował pionierską pracę: „The Political System: An Inquiry into the State of Political Science”, w której jako pierwszy zaproponował wykorzystanie kategorii badawczej systemu do badania życia politycznego państwa (zob. Easton, 1953; Pawłuszko, 2004). Obecnie stanowi ona jedno z podstawowych elementów metodologicznego zaplecza każdego przedstawiciela nauk o polityce (Pietraś, 2015). Zaproponowana przez Eastona metoda badawcza oparta jest na modelu systemu jako złożonej, funkcjonalnej całości oddzielonej od otoczenia za pomocą granic. W granicach tkwią wyspecjalizowane aparaty wejścia i wyjścia, odpowiedzialne odpowiednio za odbieranie bodźców z otoczenia i wykonywanie reakcji na nie. Przekształcanie otrzymywanych na wejściu bodźców w reakcje wyjściowe dokonuje się w procesie konwersji wewnątrzsystemowej. Każde działanie systemu wywołuje reakcję otoczenia (przyjmując, że brak reakcji jest również reakcją), reprezentowaną przez przebiegające od wyjścia do wejścia sprzężenie zwrotne.

Jak wynika z powyższego opisu, analiza systemowa oparta jest na stosowaniu specyficznego modelu analitycznego, funkcjonującego w oparciu o cykle oddziaływań pomiędzy systemem i jego środowiskiem. Każdy element struktury systemu posiada własną specyfikę, a analiza każdego z nich powinna stanowić kolejny krok procedury badawczej. Wszystko to oznacza, że omawiany model zawiera w sobie nie tylko strukturę przedmiotu badań, ale również streszcza schemat procedury badawczej.

Metoda analizy systemowej charakteryzuje się szeregiem zalet, spośród których najważniejszymi są: dostrzeganie procesualnego charakteru rzeczywistości politycznej oraz rozpatrywanie każdego systemu jako podsystemu większej całości, z którą dąży on do utrzymania dynamicznej równowagi (von Bertalanffy, 1976). Na tych dwóch przymiotach opiera się trzeci: zdolność do identyfikowania prawidłowości funkcjonowania systemu w zmieniającym się otoczeniu. Za wszystkie te korzyści przychodzi jednak zapłacić cenę istotnego 
ograniczenia. Jak wynika $\mathrm{z}$ samej istoty rozważanej metody, jej stosowanie związane jest $\mathrm{z}$ wyodrębnieniem ze świata - całości, która będzie rozpatrywana jako system. To w odniesieniu do niej znaczenia nabierają kategorie analityczne: granic, wejścia, wyjścia, konwersji wewnątrzsystemowej i sprzężenia zwrotnego. W sytuacji, gdy ich wyodrębnienie jest niemożliwe, analiza systemowa nie może być stosowana.

Jak zauważył Z. J. Pietraś (1986), system międzynarodowy można zdefiniować zarówno w odniesieniu do całości, jak i poszczególnych płaszczyzn stosunków międzynarodowych. W obu tych sytuacjach jego elementami są różnorodni aktorzy, zaś łączącymi je relacjami -interakcje i procesy transgraniczne. Właśnie ze względu na cechę transgraniczności relacji oraz specyfikę zakresu przedmiotowego powiązań można wyznaczyć granicę oddzielającą wnętrze systemu międzynarodowego od reszty rzeczywistości. Jednak dla badacza stosunków międzynarodowych znacznie bardziej interesujące będzie jego wnętrze, wewnętrzna dynamika oraz mechanizmy funkcjonowania i tendencje rozwoju. Granice systemu staną się zarazem granicami przedmiotu badań, a jeśli tak, wskazywanie na 'elementy' wejścia, wyjścia i mechanizm sprzężenia zwrotnego stanie się bezprzedmiotowe. Wobec braku 'zewnętrza' systemu swoje znaczenie traci również kategoria konwersji wewnątrzsystemowej. W ten sposób analiza systemowa załamuje się, mimo że przedmiot badań spełnia definicję systemu w sensie ogólnym, co jest przykładem granic jej stosowalności.

Można zauważyć, że system w rozumieniu metody spełnia, ale nie wyczerpuje zakresu znaczeniowego ogólnej definicji systemu jako takiego. Jako system mogą być bowiem definiowane również takie obiekty, w stosunku do których analiza systemowa traci na użyteczności. Pojawia się w ten sposób potrzeba konstrukcji analitycznej, która z jednej strony będzie traktowała analizę systemową jako swój szczególny przypadek, $\mathrm{z}$ drugiej natomiast będzie nadawała się do opisu dowolnego systemu, bez względu na specyficzne cechy jego struktury i części składowych. Mówiąc obrazowo, konstrukcja ta powinna mieć charakter „tkanki łącznej”, rozpiętej między ogólnym i metodologicznym rozumieniem systemu, unifikującej oba w ramach jednej, logicznej struktury, zachowującej elastyczność ze względu na przedmiot badań.

W toku dotychczasowych rozważań udało się udowodnić, że zarówno system w znaczeniu ogólnym, jak i metodologicznym jest strukturą sieciową. W kontekście pierwszej wierzchołki oraz krawędzie są immamentnymi elementami systemu, bez których w ogóle nie da się go konceptualizować. Z kolei analiza systemowa okazuje się być szczególnym sposobem interpretacji sieci 
cyklicznej. Pozwala to sądzić, że poszukiwanym uogólnieniem jest właśnie sieć. Ustaliwszy to na gruncie teoretycznym, należy przełożyć ten wniosek na konkretne procedury badawcze, mogące rzucić nowe światło na zjawiska i procesy międzynarodowe.

\section{ANALIZY SIECIOWE W NAUKACH SPOŁECZNYCH}

Analiza systemowa jest dotychczas jedyną metodą wykorzystywaną na gruncie nauk o polityce, która odwołuje się do modelu sieciowego. W tej sytuacji, chcąc przedstawić ją jako szczególny przypadek szerszej klasy narzędzi analitycznych, należy wyjść poza obszar badań szeroko pojętej politologii i zapoznać się z dorobkiem innych nauk w zakresie badań nad strukturami sieciowymi. Interesujący będzie przy tym nie tylko kontekst sieci społecznych.

Początki badań nad sieciami sięgają wieku XVIII i narodzin matematycznej teorii grafów. W roku 1736 szwajcarski matematyk Leonhard Euler rozważał zagadnienie znane jako „problem mostów królewieckich” (Wojciechowski, Pieńkosz, 2013). Polegało ono na wyznaczeniu takiej trasy spaceru przez miasto, aby po wyjściu $\mathrm{z}$ domu, wrócić do niego, przechodząc dokładnie raz przez każdy z komunikujących miasto mostów (Wilson, 2012). Euler rozwiązał problem, rozważając własności grafu odpowiadającego topografii Królewca i zauważył, że logika jego badań prowadzi do powstania swego rodzaju „nowej geometrii” (Oh, Monge, 2016). O ile w geometrii klasycznej kluczowe znaczenie odgrywały miary kątów, długości odcinków, pola powierzchni figur płaskich lub objętości brył, o tyle „nowa geometria” Eulera przenosi ciężar badań na rozważania struktur rozumianych nie jako konkretne formy przestrzenne, lecz ogólne schematy skomunikowania. Jedną i tę samą sieć można zobrazować na wiele sposobów, jednak każdy z nich charakteryzować się będzie tym samym układem połączeń między elementami, co nazwano topologią sieci (Cornacchio, 1976).

Nurt badań zapoczątkowany przez Eulera szybko rozwinął się w osobną gałąź matematyki, znaną jako Teoria Grafów (Wojciechowski, Pieńkosz, 2013). O ile jednak w naukach formalnych bardzo szybko nastąpił jej dynamiczny rozwój, to jej potencjalną użyteczność dla nauk społecznych dostrzeżono dopiero w latach 30. XX wieku w socjologii (Kowalska-Musiał, 2013). Ponieważ rzeczywistość społeczna odznacza się nieustannie wzrastającą dynamiką przemian, przypuszczenie o istnieniu wewnątrz niej pewnych stałych struktur słusznie mogło wydawać się nieuzasadnione. Tymczasem rozważanie więzi o istotnym znaczeniu dla uczest- 
ników, w których podtrzymanie inwestują oni wiele czasu i energii, pokazało że po pierwsze, struktura takich sieci jest trudna do zmiany, po drugie, pozycja zajmowana przez poszczególnych aktorów w sieci ma związek $\mathrm{z}$ ich zachowaniami. Fakt jeszcze znamienniejszy został odkryty w latach 50. XX w. przez Alexandra Bevelas'a (Oh, Monge, 2016). Wykazał on, że istniejące przez długi czas sieci relacji określonego rodzaju, wykazują tendencję samorzutnej rekonfiguracji do specyficznej topologii. Tym samym istnieje związek pomiędzy charakterem relacji a kształtem tworzonych przez nie sieci. Jeżeli poddać analizie pozycje zajmowane wewnątrz sieci przez wierzchołki odpowiadające poszczególnym podmiotom, będą one korespondowały z pełnionymi przez nie rolami. Innymi słowy, badając matematyczne własności grafów odpowiadających fragmentom rzeczywistości społecznej, jesteśmy w stanie otrzymane wyniki „przetłumaczyć” na dane jakościowe, dostarczające nowej wiedzy. Jest to fakt zdumiewający, tym bardziej że to właśnie świat społeczny jest zwykle kojarzony z chaotycznością $\mathrm{i}$ indeterminizmem (Frankowski, 2002).

Wspomniane powyżej badania prowadzone były na gruncie socjologicznym i jeśli posiadały znaczenie dla nauk o polityce, to w sensie pośrednim. W latach 90. ubiegłego wieku nastąpiły jednak odkrycia, które dostarczyły wyników o znaczeniu politologicznym par excellance. W roku 1998 Rosario Mantegna, badając międzynarodowe rynki finansowe, założył, że użycie w stosunku do nich terminu "przestrzeń" jest nie tylko obrazowym sposobem opisu, lecz pozwala także na ujęcie ich rzeczywistych cech (Mantegna, 1999). W zdefiniowanej przez niego przestrzeni poszczególne punkty odpowiadają uczestnikom badanych rynków, natomiast sposób liczenia odległości między nimi wynika ze stopnia ich wzajemnego skorelowania pod względem wskaźników giełdowych. Nieoczekiwanie rozważania tak abstrakcyjnego, matematycznego obiektu, doprowadziły do otrzymania konkretnych wyników w postaci hierarchicznych struktur powiązań pomiędzy przedsiębiorstwami. Poszukując jak najkrótszych ciągów połączeń, reprezentujących możliwie jak najsilniejsze powiązania, Mantegna skonstatował, że odpowiadają one pewnemu specyficznemu rodzajowi grafów, znanemu jako „minimalne drzew spinające” (Bondy, Murty, 1976). Reprezentowały one zasięgi oddziaływań najważniejszych graczy na wybranych sektorach rynku, a ponadto pozwalały na wskazanie stopni zależności, w jakich pozostawali najważniejsi partnerzy biznesowi. Jako że w konstrukcji modelu uwzględniono upływ czasu, otrzymane wyniki posiadały również wartość prognostyczną.

Nie ulega wątpliwości, że wnioski, do jakich doszedł Rosario Mantegna, posiadają znaczenie również dla nauki o stosunkach międzynarodowych. $Z$ tego 
punktu widzenia naturalnym jest zastosowanie metody włoskiego badacza do analizy rynków o znaczeniu strategicznym. W roku 2015 dokonali tego dwaj badacze z Chińskiej Akademii Nauk w Pekinie: Quiang Yi i Ying Fan. Analizując międzynarodowy rynek ropy naftowej, udowodnili, że w miarę jego postępującej integracji rośnie również jego wrażliwość na zagrożenia o charakterze systemowym, które mogą zostać zbalansowane jedynie poprzez pewną formę „kolektywnego zarzadzania” (Yi, Fan, 2015). Wobec jego braku rosnący stopień współzależności surowcowo-energetycznych między państwami paradoksalnie odbija się negatywnie na stabilności rynków jako całości.

Najnowszy przykład zastosowania sieciowych metod badawczych w naukach o polityce pochodzi z roku 2019. Członkowie Grupy Badawczej Polityki Energetycznej Uniwersytetu w Cambridge: David Woroniuk, Arze Karam oraz Tooraj Jasamb, stosując oparte na prawdopodobieństwie metody analityczne, zbliżone w swej logice do badań Mantegny, Yi i Fao, poddali badaniom korelacje cen kształtujących się na hubach handlu gazem ziemnym w Europie (Woroniuk, Karam, Jasamb, 2019).

Oceniając przytoczone przykłady badań wykorzystujących struktury sieciowe w naukach społecznych, można zauważyć, że chociaż pochodzą one $\mathrm{z}$ różnych dyscyplin, za wszystkimi stoi ten sam schemat projektowania procesu badawczego. Punkt wyjścia stanowi formalizm matematyczny teorii grafów, zawierający w sobie nie tylko pojęcia użyteczne do opisu sieci, ale również procedury wyodrębniania z całości niejednokrotnie skomplikowanych sieci struktur o specyficznej topologii. Opanowanie go, nawet na podstawowym poziomie, oferuje badaczowi istotne korzyści, ponieważ prowadzi do operacjonalizacji badań poprzez znalezienie odpowiedniości między terminami teorii grafów a siatką pojęciową danej dziedziny wiedzy.

Podobnie jak dla Eulera wierzchołki grafu odpowiadały częściom Królewca, krawędzie zaś reprezentowały mosty; tak samo mogą one w socjologii reprezentować ludzi, ich relacje i znajomości, w ekonomii - przedsiębiorstwa i powiązania między nimi, w stosunkach międzynarodowych zaś - państwa i łączące je granice, umowy międzynarodowe i ich strony, trasy podróży dyplomatycznych czy szlaki komunikacyjne.

Powyższa operacjonalizacja otwiera możliwości zbudowania, w oparciu o dane empiryczne, modeli fragmentów rzeczywistości, które pragniemy zbadać. Sieci, jakie opisał Bevelas, stanowiły obraz znajomości między ludźmi należącymi do próby badawczej. Z kolei Mantegna, Yi i Fan oraz badacze z Cambridge stworzyli swego rodzaju „mapy” badanych rynków, w których poszukiwali szcze- 
gólnych struktur, opisujących korelacje cenowe i połączenia infrastrukturalne. Należy zaznaczyć, że minimalne drzewa spinające nie są jedynymi strukturami, których identyfikację umożliwia teoria grafów. Ciekawe wnioski można również wysnuć z analizy dróg maksymalnego przepływu, które w odniesieniu na przykład do handlu międzynarodowego posiadają znaczenie strategiczne.

Ostatnim krokiem badawczym, podejmowanym w rozważanych przykładach, jest interpretacja otrzymanych wyników w duchu reprezentowanej przez badaczy dziedziny wiedzy. Po raz kolejny uwidacznia się tu kluczowe znaczenie zidentyfikowanych wcześniej odpowiedniości, pomiędzy specyficznymi strukturami grafów a realnie istniejącymi wzorami relacji. Mówiąc obrazowo, stanowią one „słownik” umożliwiający „przetłumaczenie” wyników matematycznych na język danej dyscypliny i tym samym otrzymanie wyników podlegających dalszej interpretacji i dyskusji.

Wszystkie powyższe rozważania wypada zakończyć próbą zaaplikowania zaproponowanego wyżej modelu na grunt jednej z teorii systemu międzynarodowego. Daje się zauważyć, że szczególnie dobrze nadaje się do tego celu teoria „systemów-światów” lub „gospodarek- światów”, pochodząca od Immanuela Wallersteina . Jest ona na tyle dobrze znana i szeroko komentowana, że powinna stanowić reprezentatywny przykład użyteczności dotychczasowych wyników.

W teorii Wallersteina pojęcie gospodarki-świata odnosi się do jednego systemu ekonomicznego, łączącego obszary geograficzne znajdujące się pod jurysdykcją wielu autonomicznych ośrodków władzy (Czaputowicz, 2008). W chwili obecnej cały glob przynależy do jednej gospodarki-świata, funkcjonującej w oparciu o reguły kapitalizmu. Determinuje ona rzeczywistość społeczną, narzucając jej uczestnikom konieczność działania zgodnie z logiką akumulacji kapitału. W zależności od wielkości zysków oferowanych przez poszczególne obszary geograficzne, kapitał przepływa z miejsc oferujących mniejsze zyski tam, gdzie są one większe. Tym samym powstaje funkcjonalny podział pracy determinujący podział systemu na trzy obszary: centrum - posiadające środki produkcji i eksportujące towary przetworzone; peryferia - pozostające na usługach centrum, jako zaplecze surowcowe i rynki zbytu; oraz półperyferia. Te ostatnie zajmują miejsce pośrednie pomiędzy peryferiami i centrum, zapewniając całemu systemowi stabilność polityczno-ekonomiczną.

Podobnie jak każdy system gospodarka-świat tworzy całościowy system dzięki spinającym je połączeniom. W rozważanym przypadku są nim przepływy kapitału pozostające w ścisłym związku pomiędzy przepływami surowców eksportowanych przez peryferia i półperyferia do centrum; oraz towarów prze- 
tworzonych importowanych w przeciwną stronę. Mając to na uwadze, model analityczny gospodarki-świata należy zdefinować jako sieć będącą sumą dwóch podgrafów rozpiętych na tym samym zbiorze wierzchołków. Pierwszy podgraf opisywać będzie przepływy surowców, drugi - towarów przetworzonych. Ponieważ każdy przepływ jest relacją kierunkową, jego reprezentacją będzie krawędź zakończona na jednym końcu strzałką i nazywaną łukiem (Wilson, 2012). Do każdego łuku należy przypisać wartość (wagę) odpowiadającą wielkości wolumenów transportowanego dobra. W ten sposób otrzymamy strukturę określaną jako digraf ważony (Bondy, Murty, 1976). Zebrane dane empiryczne pozwolą stwierdzić, które wierzchołki łączą łuki oraz jakie są ich wagi.

Jeśli teoria Immanuela Wallersteina odpowiada rzeczywistości, wówczas obie otrzymane podsieci powinny charakteryzować się zbliżonymi, lecz w pewnym sensie przeciwnymi topologiami. Sieć przepływów surowcowych powinna posiadać wiele peryferyjnych „wierzchołków źródłowych”, to znaczy takich, z których łuki jedynie wychodzą. Poruszając się zgodnie z kierunkami połączeń o największych wagach i przyjmując zasadę niepowracania do wierzchołków już raz odwiedzonych, badacz powinien zostać doprowadzony finalnie do zidentyfikowania względnie nielicznej grupy państw centrum, które wyłącznie importują surowce albo reeksportują dalej tylko ich niewielkie ilości. Odwrotna prawidłowość powinna zachodzić dla sieci przepływów towarów przetworzonych. Rozpoczynając analizę od niewielu wierzchołków źródłowych, identyczny algorytm powinien doprowadzić do znalezienia wielu „wierzchołków-ujść”. Aby mieć pewność, że obie struktury są ze sobą skorelowane, ciągi połączeń wyznaczone w jednym podgrafie powinny posiadać swoje odpowiedniki w drugim, od których powinny się różnić jedynie kierunkami odpowiadających sobie łuków i możliwie zbliżonym zbiorem wierzchołków.

\section{WNIOSKI}

Przeprowadzona analiza pozwala na sformułowanie kilku wniosków. Po pierwsze sieć, nazywana również grafem, jest rodzajem meta-struktury, za pomocą której można opisać każdą strukturę złożoną z obiektów połączonych relacjami. Obiekty te mogą w szczególności odpowiadać zjawiskom politycznym, w tym międzynarodowym. Zawężając stosunki międzynarodowe do transgranicznych interakcji różnorodnych podmiotów, w sytuacji posiadania rozbudowanej bazy danych empirycznych możliwa byłaby ich wizualizacja za pomocą modelu siecio- 
wego. Przedsięwzięcie takie jest $\mathrm{z}$ oczywistych względów niewykonalne, jednak jeżeli odpowiednio wąsko zdefiniować przedmiot zainteresowań, w kategoriach jednego rodzaju oddziaływań lub powiązań pomiędzy określoną grupą aktorów, staje się możliwe do realizacji. Należy przy tym zwrócić uwagę, że użyteczność kategorii badawczej sieci rozciąga się zarówno na struktury horyzontalne, jak i hierarchiczne. Ponieważ oba te rodzaje struktur zajmują w stosunkach międzynarodowych poczesne miejsce, można zaryzykować stwierdzenie, że sieć opisująca stosunki międzynarodowe ma cechy heterarchii.

Po drugie metoda analizy systemowej jest jednym $z$ najważniejszych narzędzi poznawczych pozostających do dyspozycji badaczy stosunków międzynarodowych. Pomimo niewątpliwych zalet nie nadaje się ona jednak do badania wszystkich systemów, w szczególności takich, które mogą być rozpatrywane z pominięciem ich interakcji z otoczeniem. Takim systemem jest niewątpliwie system międzynarodowy, który możemy opisać jako „samosprzężony”, gdyż najważniejsze sprzężenia zwrotne każdego z jego podsystemów również się w nim zawierają. Ograniczenia te mogą być skutecznie przezwyciężone poprzez zastosowanie analizy sieciowej, uogólniającej analizę systemową jako szczególny przypadek szerszej klasy metod badawczych.

Po trzecie analiza struktur sieciowych jest nurtem badań strukturalnych zapoczątkowanym w XVIII wieku i opartym na matematycznej teorii grafów. Jej użyteczność badawcza w obszarze nauk społecznych została pierwotnie wykazana w socjologii, a następnie rozprzestrzeniała się na kolejne dyscypliny naukowe, takie jak ekonomia, nauki o komunikowaniu, a obecnie również szeroko pojęte nauki o polityce. Analiza różnorodnych przykładów zastosowania analizy sieciowej w naukach społecznych pozwala zauważyć, że wszystkie one oparte są na interdyscyplinarnie użytecznym schemacie projektowania procesu badawczego. Mimo iż w warstwie opisu badanych struktur posługuje się on językiem matematyki, można dokonywać jego interpretacji w duchu konkretnych dyscyplin nauk społecznych. Umożliwiają to identyfikowane w procesie operacjonalizacji badań odpowiedniości pomiędzy pojęciami matematycznymi a czynnikami charakteryzującymi zjawiska i procesy społeczne.

Po czwarte badania sieciowe w naukach społecznych są rozwijającym się nurtem badań interdyscyplinarnych, który do tej pory nie został podjęty na gruncie nauki polskiej. Tym samym stanowi perspektywiczny i wartościowy kierunek badań na gruncie stosunków międzynarodowych, tym bardziej że okazuje się korespondować również z paradygmatami o uznanym statusie naukowym. 
Bibliografia:

Baumann, R., Dingwerth, K. (2014). Global governance vs empire: Why world order moves towards heterarchy and hierarchy, Journal of International Relations and Development, 18(1), 104-128.

Bertalanffy von, L. (1976). Historia rozwoju i status ogólnej teorii systemów. W: G. J. Klir (red.). Ogólna Teoria Systemów (ss. 27-48). Warszawa: Wydawnictwo NaukowoTechniczne.

Bondy, J. A., Murty, U., S., R. (1976). Graph Theory with applications. New York: Elsevier Science Publishing.

Burton, J. W. (1972). World Society. Cambridge University Press.

Buzan, B., Little, R. (2011). Systemy Międzynarodowe $w$ historii świata. Warszawa: Wydawnictwo Naukowe PWN.

Castells, M. (1996). Społeczeństwo Sieci. Warszawa: Wydawnictwo Naukowe PWN.

Cornacchio, J. V. (1976). Pojęcia topologiczne w matematycznej teorii systemów ogólnych. W: G. J. Klir (red.). Ogólna Teoria Systemów (ss. 293-327). Warszawa: Wydawnictwo Naukowo-Techniczne.

Czaputowicz, J. (2008). Teorie Stosunków Międzynarodowych: krytyka i systematyzacja. Warszawa: Wydawnictwo Naukowe PWN.

Dumała, H. (2007). Transnarodowe Sieci w Stosunkach Międzynarodowych. W: M. Pietraś (red.) Międzynarodowe Stosunki Polityczne (ss. 208-222). Lublin: Wydawnictwo UMCS.

Dymała, H. (2012). Transnarodowe Sieci Terytorialne w Europie. Lublin: Wydawnictwo UMCS.

Easton, D. (1953). The Political System: An Inquiry into the State of Political Science, New York: A. Knopf.

Frankowski, P. (2002). Stosunki międzynarodowe jako system chaotyczny. Annales Universitatis Mariae Curie- Skłodowska, Sectio K, Politologia, IX, 21-30.

Ji, Q., Fan, Y. (2016). Evolution of the crude oil market integration: a graph theory analysis. Energy Economics, 53, 90-100.

Kondrakiewicz, D. (2015). Między Porządkiem a chaosem. Faza Nierównowagi Systemu Międzynarodowego. Lublin: Wydawnictwo UMCS.

Kondrakiewicz, D. (2016). System międzynarodowy jako kategoria w nauce o stosunkach Międzynarodowych. TEKA Komisji Politologii i Stosunków Międzynarodowych, 11(3), 75-94.

Kowalska-Musiał, M. (2013). Strukturalna metodologia pomiaru sieci społecznych - rys historyczny i współczesne obszary zastosowań. Zeszyt Naukowy Wyższej Szkoły Zarządzania i Bankowości w Krakowie, 28(15).

Mantegna, R. (1999). Hierarchical Structure in Financial Markets. The European Physical Journal B-Condensed Matter and Complex Systems, 11, 193-197.

Miura, S. (2003). The Heterarchical Society: Networks and Authorities in World Politics Institutionalization of International Relations. International Relations, 132, 58-76.

Oh, P., Monge, P. (2016). Network Theory and Models. W: K. B. Jensen, R. T. Craig, 
J. D. Pooley, E. W. Rothenbuhler (red.). The International Encyclopedia of Communication Theory and Philosophy, Pobrane z: https://onlinelibrary.wiley.com/doi/ full/10.1002/9781118766804.wbiect246.

Pawłuszko, T. (2014). Kategoria systemu międzynarodowego w NSM. Pobrane z: https:// www.researchgate.net/publication/314759404_Kategoria_systemu_miedzynaro dowego_w_NSM.

Pietraś Z. J. (1986). Podstawy Teorii Stosunków Międzynarodowych. Lublin: Wydawnictwo UMCS.

Pietraś, M. (2007). Istota i ewolucja międzynarodowych stosunków politycznych. W: M. Pietraś (red.). Międzynarodowe Stosunki Polityczne (ss. 17-24). Lublin: Wydawnictwo UMCS.

Pietraś, M. (2015). Przestrzeń Badawcza Nauki o Stosunkach Międzynarodowych, Politeja, 4(36), 65-98.

Rapaport, A. (1976). Zastosowanie izomorfizmu matematycznego w ogólnej teorii systemów. W: G. J. Klir (red.). Ogólna Teoria Systemów (ss. 48- 82). Warszawa: Wydawnictwo Naukowo- Techniczne.

Slaughter, A. M. (2004). A New World Order. Princeton: Princeton University Press.

Waltz, K. N. (2010). Theory of International Politics, Illinois: Long Grove.

Wilson, R. J. (2012). Wprowadzenie do Teorii Grafów. Warszawa: Wydawnictwo Naukowe PWN.

Wojciechowski, J., Pieńkosz, K. (2013). Grafy i sieci. Warszawa: Wydawnictwo Naukowe PWN.

Woosang, K., Gates, S. (2015). Power Transition Theory and the rise of China, International Area Studies Review, 18(3), 219-226.

Woroniuk, D., Karam, A., \& Jamasb, T. (2019). European Gas Markets, Trading Hubs, and Price Formation: A Network Perspective. Pobrane z: https://www.eprg.group. cam.ac.uk. 